\title{
Experimental study on mechanical properties of different lightweight aggregate concretes
}

\author{
S.M. Samareh Hashemi*
}

Department of Civil Engineering, Islamic Azad University, Yazd Branch, Yazd Iran

\begin{tabular}{|c|c|}
\hline ARTICLE I NFO & ABSTRACT \\
\hline $\begin{array}{l}\text { Article history: } \\
\text { Received January 20, } 2014 \\
\text { Received in Revised form } \\
\text { April, } 10,2014 \\
\text { Accepted } 15 \text { April } 2014 \\
\text { Available online } \\
17 \text { April } 2014 \\
\text { Keywords: } \\
\text { Lightweight aggregate concrete } \\
\text { Compressive strength } \\
\text { Mixture density } \\
\text { Cost per metric volume }\end{array}$ & $\begin{array}{l}\text { Lightweight concrete is a suitable constructional material, which can decrease the } \\
\text { weight of buildings and the hazards of earthquake loads. Hence, a large number of } \\
\text { research studies have been focused on designing and manufacturing high strength } \\
\text { lightweight concretes. In this research using the natural and industrial lightweight } \\
\text { aggregates frequently found in the south-east region of Iran (Kerman province), high } \\
\text { strength and low cost light weight concretes were manufactured. The effects of } \\
\text { aggregate type, aggregate size, and concrete mixture were studied experimentally on } \\
\text { the compressive strength of concretes and the density and cost of manufactured } \\
\text { samples. }\end{array}$ \\
\hline
\end{tabular}

\section{Introduction}

Structural concretes including asphalt (i.e. bitumen or binder based) concrete, polymer (i.e. resin based) concrete and cement concretes are frequently used in many civil engineering applications such as roads, pavements and buildings and a large number of research studies have been performed in the past for investigating the performance and characterizing physical and mechanical properties of different types of concretes (Ibrahim et al., 2014; Soleymani Ashtiani et al., 2013; Aliha et al. 2012, 2014; Nabavi et al., 2013; Beigi et al., 2013; Paul \& van Zij1, 2013; Hussain et al., 2014; Mills-Beale $\&$ You, 2010). One of the major problems and concerns in construction of big towers and skyscrapers is the dead load induced by the weight of roofs, floors and walls. The use of light weight concrete is a possible solution for decreasing such dead loads which will lead to economic benefits as well. While the density of ordinary cement concretes is typically about $2400 \mathrm{~kg} / \mathrm{m}^{3}$ the density of low weight concrete varies typically in the range of 300 and $850 \mathrm{~kg} / \mathrm{m}^{3}$. These materials can be divided to three main categories namely(i): light weight concrete, (ii) foamed concrete and (iii) concrete without fine

\footnotetext{
* Corresponding author.

E-mail addresses: Sm.samare@gmail.com (S. M. Samareh Hashemi) 
grain aggregates. Various lightweight aggregates such as natural pumice aggregates, heat treated natural raw materials like clay, slate or shale (Leca), industrial products like fly ash and slag and etc., are frequently used for producing lightweight aggregate concretes. Improved thermal and fire resistance properties, reduction in the dead loads, savings in transporting and handling precast units on site and reduction in the formwork and propping are some of the benefits of using lightweight aggregate concretes. A large number of experimental research works have been performed in the past for designing and manufacturing lightweight aggregate concretes. In the mentioned studies some physical and mechanical properties such as thermal expansion behavior at elevated temperatures (Uygunoğlu \& Topçu, 2009), carbonation resistance (Gao et al., 2013), harsh environment effects (Thomas \& Bremner, 2012), drying shrinkage (Kayali et al., 1999), tensile creep (Zhuang et al., 2013), microstructure (Andiç-Çakır \& Hızal, 2012), durability (Heydari-rarani et al., 2014, Rossignolo \& Agnesini, 2004), fire resistance (Go et al., 2012), fracture and crack growth resistance (Aliha \& Ayatollahi, 2009; Aliha et al., 2012) and compressive strength and failure modes (Bogas \& Gomes, 2013) of lightweight aggregates concretes have been studied. However, the compressive strength of these materials is the most important parameter for designing and manufacturing the lightweight aggregate concretes.

From the practical view point, the lightweight concretes are categorized into structural and nonstructural concretes. In general the structural concretes should have 28days-compressive strengths of more than $160 \mathrm{~kg} / \mathrm{cm}^{2}$. Since the aggregate type has a main role in the strength properties of concretes, some researchers have investigated the influence of different natural and industrial aggregates including fly-ash (Lo et al., 2007, Wasserman \& Bentur, 1997; Chi et al., 2003), pumice (Sari \& Pasamehmetoglu, 2005; Libre et al., 2011), natural pozzolan (Mouli \& Khelafi, 2008), organic lightweight aggregates (Cheng et al., 2012), waste materials (Mahmud et al., 2011), dredged silt (Wang et al., 2010) clay-blended sludge (Tay et al., 1991), slag (Thomas \& Bremner, 2012), oil palm shell (Shafigh et al., 2010) and shale (Zhuang et al., 2013) on the mechanical properties of lightweight aggregate concretes. Other researchers like Kim et al. (2013), Wang and Tang (2012), Hassanpour et al. (2012) and Pan et al. (2011) studied experimentally the strength and mechanical behavior of other types of light weight concretes such as autoclaved aerated concrete, foamed concrete and fiber reinforced concretes. For those regions that are placed on the earthquake-prone areas (like Iran), the use of light weight structural materials is of great importance to decrease the risk of hazards during the earthquake. For example, the Kerman province (in the south east of Iran) is one of the hazardous regions for occurring earthquakes with magnitudes of more than 6 Richter scale (such as Bam earthquake with 6.6 Richter scale in 2003 which killed more than 50000 persons). Hence, the use of lightweight structural and constructional material is very important issue in these regions. The geological and field studies in the Kerman province have demonstrated that this region contains suitable mines for preparing lightweight aggregates for light weight concretes.

The aim of this paper is therefore, designing and manufacturing high strength light weight concretes using the aggregates frequently found in the Kerman province. The physical and strength properties of different aggregates and lightweight concretes are also determined experimentally and the cost per metric volume of each composition is compared with the cost of a typical ordinary cement concrete.

\section{Aggregates and mixture design}

Different light weight aggregates were prepared from "Shen Abad mine" in the North West of "Rafsanjan". According to the geological studies, this region has rich and extensive mines of natural aggregates such as pumice (which is favorite lightweight aggregate for manufacturing low weight and high strengths concretes). A concrete material typically consists of three main parts (i.e. cement, aggregate and water). In order to obtain an optimum composition of light weight concrete, the size of aggregates is the main parameter for obtaining a low density mixture. Two kinds of natural 
lightweight aggregates (labeled by $\mathrm{P}_{\mathrm{i}}$ and $\mathrm{T}_{\mathrm{i}}$ symbols, respectively) were considered in the first part of this research for being used in the mixtures of lightweight concrete and for each aggregate type, the water absorption percentage and the density of aggregates were determined. Table 1 presents the results of the mentioned measurements for the two types of $\mathrm{P}_{\mathrm{i}}$ and $\mathrm{T}_{\mathrm{i}}$ aggregates.

Table 1

Water absorption percentage and the density of $\mathrm{P}_{\mathrm{i}}$ and $\mathrm{T}_{\mathrm{i}}$ aggregates

\begin{tabular}{lcccc}
\hline aggregate & $\begin{array}{c}\text { Percentage of } \\
\text { water absorption } \\
\text { after 0.5hours }\end{array}$ & $\begin{array}{c}\text { Percentage of water } \\
\text { absorption after } 24 \\
\text { hours }\end{array}$ & $\begin{array}{c}\text { Density }\left(\mathrm{gr} / \mathrm{cm}^{3}\right) \\
\text { @ oven-dry (air) }\end{array}$ & $\begin{array}{c}\text { Density }\left(\mathrm{gr} / \mathrm{cm}^{3}\right) \\
\text { @ saturated- } \\
\text { surface-dry (SSD) }\end{array}$ \\
\hline Type 1 $\left(\mathrm{P}_{\mathrm{i}}\right)$ & 12 & 12.5 & 1.28 & 1.35 \\
Type 2 $\left(\mathrm{T}_{\mathrm{i}}\right)$ & 11 & 11.8 & 1.37 & 1.43 \\
\hline
\end{tabular}

Fig. 1 shows the distribution of aggregate gradation used in this research for preparation of concrete mixture using the two aggregate types.

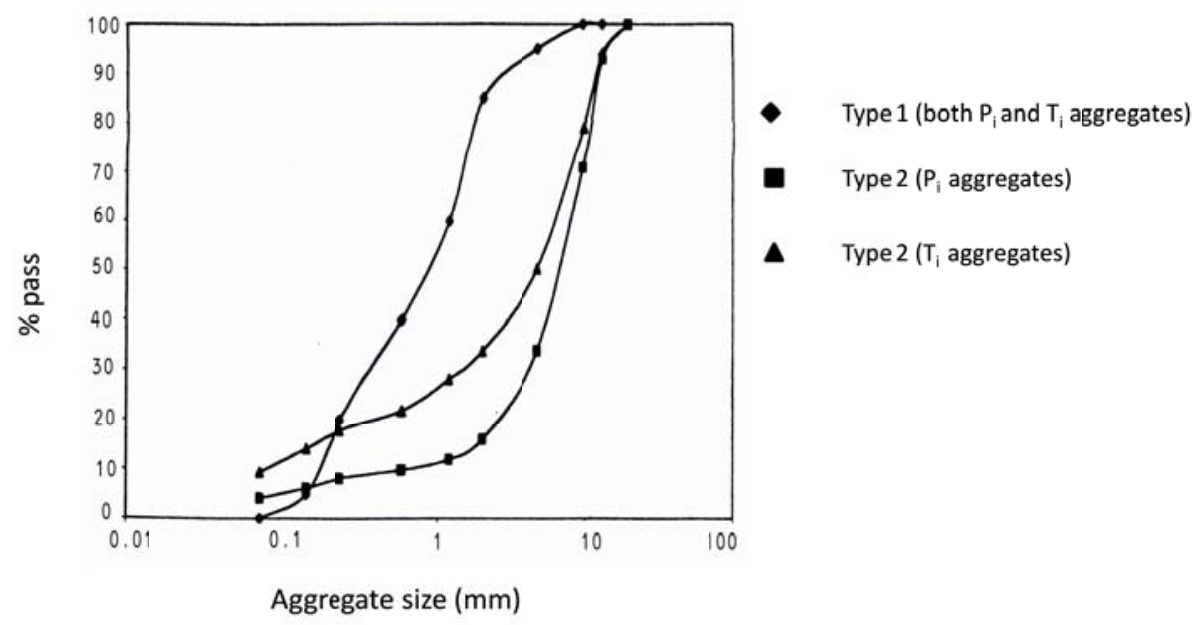

Fig. 1. Aggregate gradation of $P_{i}$ and $T_{i}$ samples.

Using the mentioned aggregates, several mixtures were designed according to ASTM C33. For each mixture the composition of concrete including the cement, water, aggregate and filler contents were determined based on the available formulations presented in ASTM C33. The mixture composition of each concrete has been presented in Table 2 .

Table 2

Mixture composition of concretes with different aggregates

\begin{tabular}{lcccccc}
\hline $\begin{array}{l}\text { Sample } \\
\text { No. }\end{array}$ & $\begin{array}{c}\text { Condition of } \\
\text { used } \\
\text { aggregate }\end{array}$ & $\begin{array}{c}\text { Aggregate } \\
\text { gradation } \\
\text { type }\end{array}$ & $\begin{array}{c}\text { Cement } \\
\text { content } \\
\mathrm{kg} / \mathrm{m}^{3}\end{array}$ & $\begin{array}{c}\text { Water content } \\
\mathrm{Lit} / \mathrm{m}^{3}\end{array}$ & $\begin{array}{c}\text { Aggregat } \\
\text { e content } \\
\mathrm{kg} / \mathrm{m}^{3}\end{array}$ & $\begin{array}{c}\text { Filler content } \\
\mathrm{Kg} / \mathrm{m}^{3}\end{array}$ \\
\hline $\mathrm{P}_{1}$ & SSD & 2 & 300 & 150 & 300 & - \\
$\mathrm{P}_{2}$ & SSD & 2 & 450 & 200 & 320 & - \\
$\mathrm{P}_{3}$ & SSD & 2 & 450 & 180 & - & Micro silica 70 super plasticizer 60 \\
$\mathrm{P}_{4}$ & SSD & 1 & 450 & 210 & - & - \\
$\mathrm{P}_{\mathrm{e}}$ & SSD & 1 & 450 & 210 & - & - \\
$\mathrm{P}_{\mathrm{A}}$ & Dried at air & 2 & 300 & 290 & - & - \\
$\mathrm{T}_{1}$ & SSD & 2 & 500 & 140 & 320 & Micro silica 70 super plasticizer 60 \\
$\mathrm{~T}_{2}$ & SSD & 2 & 500 & 230 & 320 & - \\
$\mathrm{T}_{3}$ & Dried at air & 2 & 450 & 260 & - & - \\
$\mathrm{T}_{\mathrm{e}}$ & SSD & 1 & 450 & 200 & - & - \\
\hline
\end{tabular}


The prepared mixtures were then inserted to molds of $100 * 100 * 100 \mathrm{~mm}^{3}$ to obtain cubic test samples made from different compositions. At least 3 test samples were manufactured from each mixture and the test samples were maintained for 7, 14, 21 and 28 days. Then they were subjected to a compressive load (according to AASHTO (1995)) using a $10 \mathrm{kN}$ test machine with the loading rate of $0.5 \mathrm{~mm} / \mathrm{min}$ to obtain the compressive strength of the manufactured concretes. It should be noted that in addition to $P_{i}$ and $T_{i}$ samples, other lightweight aggregates available in the Kerman province such as Leca, Perlite, pumice and copper slag furnace were also used for manufacturing other lightweight concretes. In the next section, the experimental results are presenterd and discussed.

\section{Results and Discussion}

Table 3 summarizes the average of test results obtained for different light weight concretes. In Fig. 2 the compressive strength versus density of $P_{i}$ and $T_{i}$ samples have been compared. As seen from this figure, the mixtures made from $T_{i}$ aggregates provide greater strengths in comparison with $P_{i}$ samples. The cost of samples made from $P_{i}$ and $T_{i}$ samples with respect to ordinary cement concretes have been compared in Fig. 3. Based on this figure the mixtures made of $T_{3}$ and $T_{2}$ aggregates provide the highest compressive strength with the lowest cost.

\section{Table 3}

Results obtained for the density, compressive strength and cost of different lightweight aggregate concretes tested in this research

\begin{tabular}{|c|c|c|c|}
\hline Sample name & Density $\left(\mathrm{kg} / \mathrm{m}^{3}\right)$ & $\begin{array}{l}\text { 28days compressive } \\
\text { strength }\left(\mathrm{kg} / \mathrm{cm}^{2}\right)\end{array}$ & $\begin{array}{l}\text { Cost per metric volume/ cost per } \\
\text { metric volume of ordinary concrete }\end{array}$ \\
\hline $\mathrm{P}_{1}$ & 1650 & 125 & 1.15 \\
\hline $\mathrm{P}_{2}$ & 1670 & 200 & 1.2 \\
\hline $\mathrm{P}_{3}$ & 1700 & 300 & 1.2 \\
\hline $\mathrm{P}_{4}$ & 1630 & 163 & 1.2 \\
\hline$P_{e}$ & 1630 & 155 & 1.2 \\
\hline $\mathrm{P}_{\mathrm{A}}$ & 1640 & 350 & 2 \\
\hline $\mathrm{T}_{1}$ & 1610 & 190 & 1.1 \\
\hline $\mathrm{T} 2$ & 1700 & 325 & 1.15 \\
\hline $\mathrm{T} 3$ & 1720 & 310 & 1.15 \\
\hline $\mathrm{Te}$ & 1630 & 315 & 1.3 \\
\hline Leca & 1370 & 230 & 2.2 \\
\hline perlite & 980 & 160 & 1.3 \\
\hline copper & 1430 & 180 & 1.65 \\
\hline pumice & 1480 & 90 & 1.4 \\
\hline
\end{tabular}

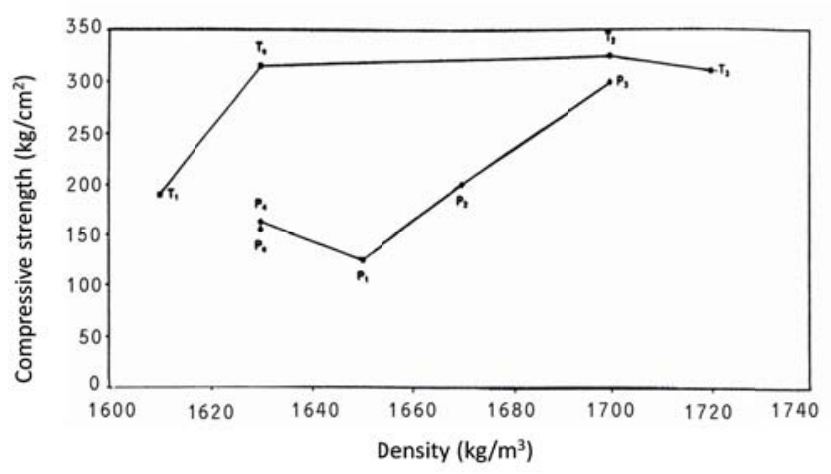

Fig. 2. Variations of compressive strength of different lightweight concretes made of $\mathrm{P}_{i}$ and $\mathrm{T}_{\mathrm{i}}$ aggregates

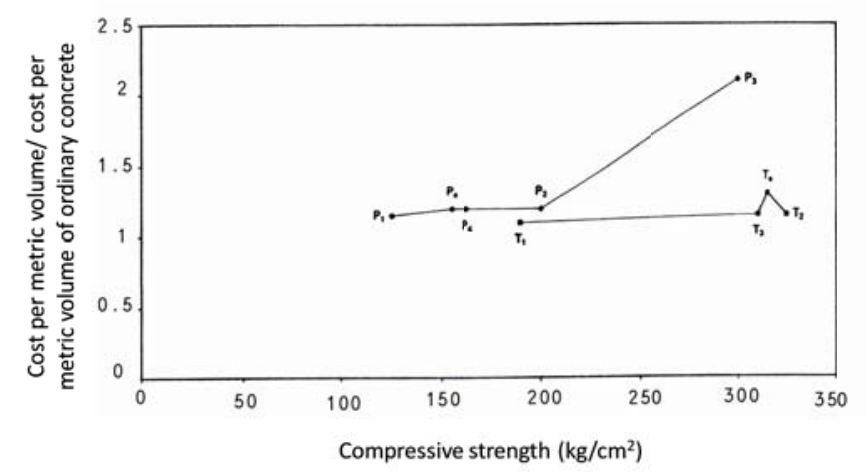

Fig. 3. Comparison of cost for different lightweight concretes made of $\mathrm{P}_{\mathrm{i}}$ and $\mathrm{T}_{\mathrm{i}}$ aggregates 
As it is clear the percentage of aggregate might have noticeable influence on the strength properties of the concretes. Hence, in the following the effect of pumice aggregate is investigated for example on the strength properties of concrete. A few concrete mixtures (i.e. A,B,C,D,E and F) were prepared using pumice aggregates according to mix design of Table 4. Some of the characteristic specifications of the pumice light weight aggregates including the density and water absorption ability in terms of time were also measured experimentally before mixing. For example, Fig. 4 presents the water absorption percentages of pumice aggregate at different times. Values of density and compressive strength of pumice concrete after 7, 14, 21 and 28 days have been also presented in Table 5. It is seen from this Table that the samples $\mathrm{C}$ and $\mathrm{D}$ have the highest compressive strength value for all the concrete ages.

\section{Table 4}

Aggregate size and the percentage of pumice used for different concrete mix designs

\begin{tabular}{lccccc}
\hline Sample & \% Pumice & \multicolumn{4}{c}{ Aggregate size (mm) } \\
& & $1-2$ & $2-5$ & $5-10$ & $10-15$ \\
\hline A & 20 & 12 & 28 & 20 & 30 \\
B & 22 & 10 & 15 & 22 & 31 \\
C & 24 & 11 & 15 & 25 & 25 \\
D & 30 & 12 & 10 & 20 & 38 \\
E & 35 & 10 & 10 & 25 & 30 \\
F & 40 & 10 & 14 & 16 & 20 \\
\hline
\end{tabular}

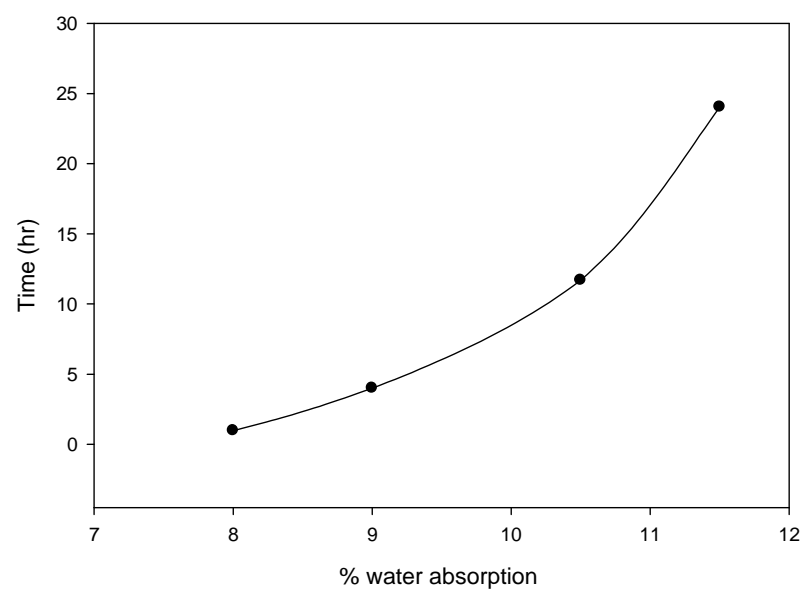

Fig. 4. Variations of water absorption of pumice aggregates with time

Table 5

Density and compressive strength of different pumice lightweight aggregate concretes

\begin{tabular}{lcccccc}
\hline Sample & \multicolumn{5}{c}{ Density of pumice concrete } & \multicolumn{4}{c}{ Compressive strength $\left(\mathrm{kg} / \mathrm{cm}^{2}\right)$} \\
\cline { 2 - 7 } & dry & SSD & 7 days & 14 days & 21 days & 28 days \\
\hline A & 1.47 & 1.65 & 120 & 230 & 250 & 290 \\
B & 1.45 & 1.50 & 110 & 240 & 265 & 300 \\
C & 1.38 & 1.40 & 105 & 245 & 270 & 310 \\
D & 1.35 & 1.38 & 105 & 250 & 265 & 315 \\
E & 1.30 & 1.35 & 104 & 245 & 260 & 307 \\
F & 1.29 & 1.32 & 102 & 240 & 260 & 305 \\
\hline
\end{tabular}


Fig. 5 shows the variations of the 28 days compressive strength with pumice percentage. Based on this figure, by increasing the pumice percentage from $20 \%$ to $24 \%$ in the composition of concrete, the compressive strength is increased but for pumice percentages greater than $30 \%$ the compressive strength of concrete is reduced. The maximum strength is achieved when the pumice content is between $24 \%$ and $30 \%$.

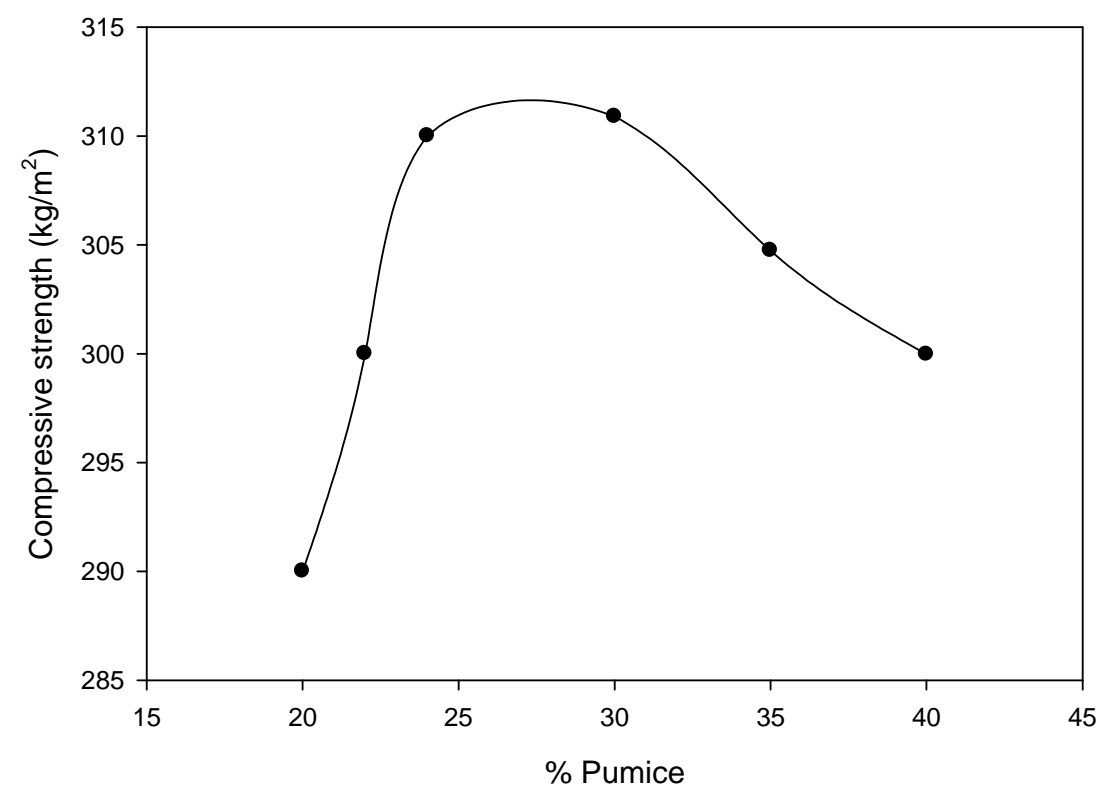

Fig. 5. Variations of 28days compressive strength with different percentages of pumice in the composition of concrete

\section{Conclusions}

- Different lightweight aggregate concretes with the aggregates that are frequently found in south east of Iran were designed and manufactured.

- The effects of aggregate type, composition and percentage of aggregates were studied on the density and compressive strength of light weight aggregate concretes.

- Samples $T_{2}$ and $T_{3}$ had the greatest strength and also lowest price. Hence, they can be considered as favorite concretes for being used in structural applications.

- The maximum strength for pumice concrete was obtained for mixtures containing $24 \%$ to $30 \%$ pumice aggregates.

\section{References}

Aliha, M. R. M., Heidari-Rarani, M., Shokrieh, M. M., \& Ayatollahi, M. R. (2012). Experimental determination of tensile strength and K (IC) of polymer concretes using semi-circular bend(SCB) specimens. Structural Engineering and Mechanics, 43(6), 823-833.

Aliha, M. R. M., Behbahani, H., Fazaeli, H., \&Rezaifar, M. H. (2014). Study of characteristic specification on mixed mode fracture toughness of asphalt mixtures. Construction and Building Materials, 54, 623-635. 
Aliha, M. R. M., \&Ayatollahi, M. R. (2009). Brittle fracture evaluation of a fine grain cement mortar in combined tensile-shear deformation. Fatigue \& Fracture of Engineering Materials \& Structures, 32(12), 987-994.

Ameri, M., Mansourian, A., Pirmohammad, S., Aliha, M. R. M., \&Ayatollahi, M. R. (2012).Mixed mode fracture resistance of asphalt concrete mixtures. Engineering Fracture Mechanics, 93, 153167.

Andiç-Çakır, Ö.,\&Hızal, S. (2012). Influence of elevated temperatures on the mechanical properties and microstructure of self consolidating lightweight aggregate concrete. Construction and Building Materials, 34, 575-583.

Beigi, M. H., Berenjian, J., LotfiOmran, O., SadeghiNik, A., \&Nikbin, I. M. (2013).An experimental survey on combined effects of fibers and nanosilica on the mechanical, rheological, and durability properties of self-compacting concrete. Materials \& Design, 50, 1019-1029.

Bogas, J. A., \& Gomes, A. (2013).Compressive behavior and failure modes of structural lightweight aggregate concrete-Characterization and strength prediction. Materials \& Design, 46, 832-841.

Cheng, C. M., Su, D. G., He, J., \& Jiao, C. J. (2012).Compressive Strength of Organic Lightweight Aggregate Concrete. Advanced Materials Research, 374, 1531-1536.

Chi, J. M., Huang, R., Yang, C. C., \& Chang, J. J. (2003).Effect of aggregate properties on the strength and stiffness of lightweight concrete. Cement and Concrete Composites, 25(2), 197-205.

Gao, Y., Cheng, L., Gao, Z., \& Guo, S. (2013). Effects of different mineral admixtures on carbonation resistance of lightweight aggregate concrete. Construction and Building Materials, 43, 506-510.

Go, C. G., Tang, J. R., Chi, J. H., Chen, C. T., \& Huang, Y. L. (2012). Fire-resistance property of reinforced lightweight aggregate concrete wall. Construction and Building Materials, 30, 725-733.

Hassanpour, M., Shafigh, P., \& Mahmud, H. B. (2012).Lightweight aggregate concrete fiber reinforcement-a review. Construction and Building Materials, 37, 452-461.

Heidari-Rarani, M., Aliha, M. R. M., Shokrieh, M. M., \&Ayatollahi, M. R. (2014). Mechanical durability of an optimized polymer concrete under various thermal cyclic loadings- An experimental study. Construction and Building Materials, Doi: 10.1016/j.conbuildmat.2014.04.031

Hussain, H. K., Liu, G. W., \& Yong, Y. W. (2014). Experimental study to investigate mechanical properties of new material polyurethane-cement composite (PUC).Construction and Building Materials, 50, 200-208.

Ibrahim, A., Mahmoud, E., Yamin, M., \&Patibandla, V. C. (2014).Experimental study on Portland cement pervious concrete mechanical and hydrological properties. Construction and Building Materials, 50, 524-529.

Kayali, O., Haque, M. N., \& Zhu, B. (1999).Drying shrinkage of fibre-reinforced lightweight aggregate concrete containing fly ash. Cement and concrete research, 29(11), 1835-1840.

Kim, H. K., Jeon, J. H., \& Lee, H. K. (2012).Workability, and mechanical, acoustic and thermal properties of lightweight aggregate concrete with a high volume of entrained air. Construction and Building Materials, 29, 193-200.

Libre, N. A., Shekarchi, M., Mahoutian, M., \& Soroushian, P. (2011). Mechanical properties of hybrid fiber reinforced lightweight aggregate concrete made with natural pumice. Construction and Building Materials, 25(5), 2458-2464.

Lo, T. Y., Tang, W. C., \& Cui, H. Z. (2007). The effects of aggregate properties on lightweight concrete. Building and Environment, 42(8), 3025-3029.

Mahmud, H., Shafigh, P., \&Jumaat, M. Z. (2014).Structural lightweight aggregate concrete containing high volume waste materials. Key Engineering Materials, 594, 498-502.

Mills-Beale, J., \& You, Z. (2010). The mechanical properties of asphalt mixtures with recycled concrete aggregates. Construction and Building Materials, 24(3), 230-235.

Mouli, M., \&Khelafi, H. (2008).Performance characteristics of lightweight aggregate concrete containing natural pozzolan. Building and environment, 43(1), 31-36. 
Nabavi, F., Nejadi, S., \& Samali, B. (2013). Experimental investigation on mix design and mechanical properties of polymer (Latex) modified concrete. Advanced Materials Research, 687, 112-117.

Pan, L. Y., Yuan, H., \& Zhao, S. B. (2011). Experimental study on mechanical properties of hybrid fiber reinforced full lightweight aggregate concrete. Advanced Materials Research, 197, 911-914.

Paul, S. C., \& van Zijl, G. P. (2013). Mechanical and durability properties of recycled concrete aggregate for normal strength structural concrete. International Journal of Sustainable Construction Engineering and Technology, 4(1), 89-103.

Rossignolo, J. A., \&Agnesini, M. V. (2002). Mechanical properties of polymer-modified lightweight aggregate concrete. Cement and Concrete Research, 32(3), 329-334.

Rossignolo, J. A., \&Agnesini, M. V. (2004). Durability of polymer-modified lightweight aggregate concrete. Cement and Concrete Composites, 26(4), 375-380.

Sari, D., \&Pasamehmetoglu, A. G. (2005). The effects of gradation and admixture on the pumice lightweight aggregate concrete. Cement and concrete research, 35(5), 936-942.

Shafigh, P., Jumaat, M. Z., \& Mahmud, H. (2010). Mix design and mechanical properties of oil palm shell lightweight aggregate concrete: A review. International Journal of the Physical Sciences, 5(14), 2127-2134.

SoleymaniAshtiani, M., Scott, A. N., \& Dhakal, R. P. (2013).Mechanical and fresh properties of high-strength self-compacting concrete containing class $\mathrm{C}$ fly ash. Construction and Building Materials, 47, 1217-1224.

Tay, J. H., Yip, W. K., \& Show, K. Y. (1991). Clay-blended sludge as lightweight aggregate concrete material. Journal of Environmental Engineering, 117(6), 834-844.

Thomas, M., \&Bremner, T. (2012). Performance of lightweight aggregate concrete containing slag after 25years in a harsh marine environment. Cement and Concrete Research, 42(2), 358-364.

Uygunoğlu, T., \& Topçu, İ. B. (2009).Thermal expansion of self-consolidating normal and lightweight aggregate concrete at elevated temperature. Construction and Building Materials, 23(9), 3063-3069.

Uygunoğlu, T., Brostow, W., Gencel, O., \&Topçu, İ. B. (2013).Bond strength of polymer lightweight aggregate concrete. Polymer Composites, 34(12), 2125-2132.

Wang, H. Y., Sheen, Y. N., \& Hung, M. F. (2010). Performance characteristics of dredged silt and high-performance lightweight aggregate concrete. Computers and Concrete, 7(1).

Wang, Y. W., \& Tang, B. X. (2012).Experimental study of the foam agent in lightweight aggregate concrete. Applied Mechanics and Materials, 226, 1776-1779.

Wasserman, R., \&Bentur, A. (1997).Effect of lightweight fly ash aggregate microstructure on the strength of concretes. Cement and Concrete Research, 27(4), 525-537.

Zhuang, Y. Z., Chen, C. Y., \& Ji, T. (2013).Effect of shale ceramsite type on the tensile creep of lightweight aggregate concrete. Construction and Building Materials, 46, 13-18. 